Prof. Henryk Sasinowski*

\title{
KONCEPCJA RESTRUKTURYZACJI I ROZWOJU REGIONALNEGO WSCHODNIEGO POGRANICZA POLSKI
}

\section{Wstęp}

Dokonujące się przemiany w Polsce na przełomie XX i XXI wieku biorą swój początek w przeobrażeniach ustroju politycznego, co generuje liczne reformy w gospodarce narodowej. Intensywny proces transformacji systemowej i postępującej restrukturyzacji zorientowany na zasady demokratyczne umożliwił integrację regionalną i współpracę w skali mikro, mezo i makro. Przemiany ustrojowe są zarówno impulsem do otwarcia nowych możliwości, jak też próbą sprostania nowym wyzwaniom wobec władz samorządowych. Jednym z nich jest idea zintegrowanej współpracy $\mathrm{w}$ pasie nadgranicznym dokonująca się $\mathrm{w}$ ramach euroregionów. ${ }^{133}$

Celem artykułu jest naszkicowanie koncepcji restrukturyzacji i rozwoju wschodniego pogranicza Polski poprzez wypromowanie posiadanych zasobów na rzecz aktywizacji potencjału lokalnego i regionalnego. Promując własną ofertę, stwarza się szansę zdobycia na rynku mocnej pozycji w walce konkurencyjnej. Peryferyjne położenie wschodniego pogranicza stanowi istotny impuls aktywizujący potencjał wytwórczy jednostek samorządu terytorialnego przy zaangażowaniu środków pomocowych Unii Europejskiej. Pozwoli to docelowo na rozbudowę infrastruktury granicznej, tworzenie nowych miejsc pracy, ożywienie euroregionów w drodze przepływu ludzi, towarów, usług i kapitału. ${ }^{134}$

\footnotetext{
* $\quad$ Profesor w Katedrze Zarządzania Produkcją na Wydziale Zarządzania Politechniki Białostockiej.

133 Por. H. Sasinowski, Gospodarka turystyczna w aspekcie polityki i współpracy transgranicznej, [w:] Nowe wyzwania gospodarki turystycznej na poziomie lokalnym, regionalnym i międzynarodowym, red. M. Jalinik, Białystok 2011, s. 149.

134 Por. H. Sasinowski, Promocja i aktywizacja wschodniego pogranicza Polski na bazie Unii Europejskiej, [w:] Rozwój regionów wschodnich - szansa po przystąpieniu do UE, red. J.Sikorski, Białystok 2004, s. 334.
} 


\section{Polityka regionalnego rozwoju gospodarczego}

Rozwój gospodarczy jest zdeterminowany modelem ustroju politycznego kraju. Od tego zależy bowiem system władzy, struktura własności, odpowiedzialność za rozwój kraju i regionów. Wszystko to generuje nowe problemy przed teorią i praktyką polityki regionalnej. Rozwój społeczno-gospodarczy można rozpatrywać w skali kraju, regionu, subregionu, ale zawsze jest on zdeterminowany uwarunkowaniami politycznymi, ekonomicznymi, społecznymi, przyrodniczymi. Polityka regionalna jednak zawsze kojarzy się z regionem. ${ }^{135}$

Czym zatem jest region jako podmiot polityki regionalnej?

Otóż region ekonomiczny to ukształtowany lub kształtujący się układ ekonomiczny, którego elementy powiązane są między sobą i ze środowiskiem przyrodniczym relacjami współwystępowania i współzależności, a ponadto funkcjonalnie związany z całą gospodarką narodową i posiadający określony profil gospodarczy. ${ }^{136}$

Czym jest polityka regionalna w warunkach samorządności terytorialnej?

Polityka regionalna za pośrednictwem określonych instrumentów ekonomicznych zmierza do racjonalnego kształtowania procesu przemian struktury przestrzennego rozmieszczenia gospodarki i ludności na tle uwarunkowań. Polityka regionalna jest zależna od charakteru polityki gospodarczej w systemie gospodarki narodowej i obejmuje:

- wspieranie finansowe regionów najbardziej zaniedbanych gospodarczo,

- wspieranie finansowe regionów, które mają szanse stać się tzw. „biegunami wzrostu",

- ponoszenie nakładów finansowych na rekonstrukcję profilu gospodarczego regionów,

- inwestowanie w zakresie wyposażenia w infrastrukturę techniczno-ekonomiczną,

- planowanie przestrzenne polegające na racjonalnym gospodarowaniu przestrzenią, postrzegane w dwóch płaszczyznach:

- planowanie w skali ponadlokalnej (instrument przestrzennej polityki państwa),

- planowanie w skali lokalnej (instrument samorządów terytorialnych),

- łączenie kapitału publicznego z prywatnym przy podejmowaniu ważnych inwestycji,

\footnotetext{
135 H. Sasinowski, Polityka gospodarcza samorządów terytorialnych w warunkach kryzysowych, [w:] Nowe wyzwania w zakresie ekonomii i polityki gospodarczej po kryzysie subprime, red. J. Ostaszewski, Warszawa 2010, s. 413.

Polityka gospodarcza w warunkach gospodarki rynkowej, red. B. Winiarski, Warszawa 1992, s. 9.
} 
- współfinansowanie pozarządowych instytucji publicznych służących rozwojowi lokalnemu, rozwojowi małej i średniej przedsiębiorczości,

- finansowanie programów edukacji w celu przekwalifikowania zawodowego,

- promocję regionu jako miejsca korzystnych inwestycji dla kapitału z zewnątrz bądź też wspomaganie własnego kapitału w penetracji rynków obcych.

Zatem polityka regionalna, patrząc przez pryzmat planowania i zagospodarowania przestrzennego, a tym samym profilu gospodarki, może polegać na:

- działaniach władz centralnych (interregionalna), które decydują o wyborze regionów wymagających interwencji,

- działaniach władz regionalnych i gminnych (intraregionalna), które decydują o wyborze procesów gospodarczych na swoim terenie.

Polityka interregionalna w regionach wymagających interwencji ma wpływ na:

- generowanie kierunków rozwoju zbieżnych z uwarunkowaniami kraju,

- kierunki i strukturę przemian w zagospodarowaniu przestrzennym kraju,

- wspieranie koniecznej restrukturyzacji regionów problemowych i depresyjnych,

- dystrybucję międzynarodowych, a szczególnie unijnych, środków budżetowych.

Polityka intraregionalna natomiast ma wpływ przede wszystkim na:

- generowanie i wytyczanie kierunków polityki rozwoju regionów,

- końcowy kształt strategii rozwoju regionów i warunki jej realizacji,

- priorytety w zakresie kierunków zagospodarowania przestrzennego regionów.

Polityka regionalna prowadzona przez centralne organy władzy publicznej (interregionalna) jest orientowana na zachowanie względnych proporcji w rozwoju regionów. Jej przedmiotem jest krajowy i międzynarodowy system regionalny, a podmiotem rząd, który za pośrednictwem wojewodów realizuje zadania państwa.

Polityka regionalna natomiast prowadzona przez samorządowe organy władzy publicznej (intraregionalna) jest ukierunkowana na usystematyzowane procesy rozwoju społeczno-gospodarczego zachodzące w obszarze regionu. Przedmiotem polityki regionów są województwa, natomiast podmiotem - władze samorządowe.

W zakres polityki regionalnej wchodzą zatem działania władz państwowych i lokalnych obliczone na stymulowanie inicjatyw oddolnych oraz generowanie przedsiębiorczości ukierunkowanej na wzrost dynamiki gospodarki narodowej w układzie terytorialnym. Polityka regionalna jest elementem składowym polityki 
przestrzennej i stanowi podstawę realizacji celów nie tylko w ramach polityki przestrzennej i gospodarczej państwa, lecz także celów wewnętrznych regionów.

Rolę planowania przestrzennego postrzegamy jako wiodącą, ale jednak w warunkach państwa demokratycznego zawsze opartą na interakcji i kompatybilności podmiotów polityki interregionalnei i intraregionalnej. Planowanie przestrzenne ma na celu zapewnienie w miarę proporcjonalnego rozwoju kraju, regionów, gmin i miast z punktu widzenia racjonalnego użytkowania przestrzeni i środowiska oraz zapewnienie warunków rozwoju społecznego i gospodarczego. Zadaniem planowania przestrzennego jest racjonalne przekształcanie i zagospodarowanie struktur przestrzennych, z uwzględnieniem rozpoznania uwarunkowań przyrodniczych, społecznych, gospodarczych i kulturowych obszarów oraz zasad organizowania ładu przestrzennego. ${ }^{137}$

\section{Kierunki restrukturyzacji i priorytety gospodarki wschodniego pogranicza Polski}

Umierajace strzechy, najmłodsi dobiegaja pięćdziesiątki, wioski kawalerów, panny uciekly, wioska żyje póki żyja ludzie, depopulacja, depresja demograficzna, pauperyzacja!!!

To najbardziej syntetyczna a zarazem dramatyczna fotografia obszaru ,ściany wschodniej". Zjawiska typowe dla wschodniego pogranicza zostały ukształtowane w okresie powojennym - dzisiaj głównie na styku Polski-Białorusi-Ukrainy. Proces industrializacji i urbanizacji kraju wywołał zjawisko masowych migracji ludności ze wsi do miast. Ze względu na żywiołowy charakter tego zjawiska, potęgowany ograniczonością zasobów, niską jakością warunków glebowo-klimatycznych, niskim potencjałem wytwórczym, niskim poziomem życia mieszkańców, musiały wytworzyć się liczne deformacje strukturalne, które doprowadziły do zachwiania równowagi demograficznej i gospodarczej. ${ }^{138}$

Trudne warunki życia ludności wiejskiej związane z niską produkcją, brakiem pracy, odległościami w rozproszonym systemie osadniczym, brak perspektyw życia na wsi, słabe wyposażenie w infrastrukturę, to główne czynniki zniechęcające szczególnie młodych ludzi do wiązania swojej przyszłości ze środowiskiem wiejskim. ${ }^{139}$

A oto kilka wypowiedzi mieszkańców, ilustrujących dramatyczną sytuację wsi wschodniego pogranicza Polski:

137 T. Kachniarz, Z. Niewiadomski, Nowe podstawy prawne zagospodarowania przestrzennego, Warszawa 1995.

138 H. Sasinowski, Depresja demograficzna na obszarze „ściany wschodniej”, [w:] Społeczne problemy wsi, t. 2, red.

J. Bański, E. Rydz, Warszawa 2002, s. 185.

139 H. Sasinowski, Infrastruktura społeczna jako potencjalny stymulator aktywizacji wsi, Białystok 1988. 
„Z miesiąca na miesiąc, z roku na rok przybywa ruin. Pustoszeja domy, a wraz $z$ nimi również $i$ wsie. Młodych ludzi prawie się tu nie spotyka. Wszyscy pouciekali do miast, a starzy gospodaruja, tyle że sami nie wiedza już po co."

„,W połowie gospodarstw domy zamieszkuja ludzie, którzy już dawno przekroczyli 60 lat."

„Już nie pamiętam, kiedy urodziło się u nas jakieś dziecko. Za to pogrzeby mamy kilka razy $w$ roku’”.

„W naszej wsi mieszka około 150 osób, a właściwie około 140 mężczyzn i reszta. Zdarzaja się synowie, tylko córek jakoś nie widać. Kobiety trzeba tu szukać ze świeca. Są wdowy i żony, ale panny-żadnej. "

„Kobiety uciekają ze wsi. To syndrom naszych czasów. O ile mężczyźni pozostaja jeszcze na ojcowiźnie, to córki ida za lepszym życiem do miasta. Kończa szkoty, szukaja pracy i nawet myśleć nie chca o powrocie na wieś."

„, Choć jestem dopiero na studiach, wiem już, że nie wrócę na stałe do rodzinnej wsi. Chcę mieć rodzinę, marzę o dzieciach, ale chcę téż zyć, po prostu żyć."

„Na wsi nie ma właściwie przyszłości. Z roli to dzisiaj można najwyżej żyć jak dziad. Nie chce, żeby moje dzieci harowaty całe życie, dlatego nie zatrzymywałam ich na wsi, wyjechaty do Białegostoku."

Przytoczone wypowiedzi świadczą o skali zjawiska, o głębi problemów i napawają troską. Wobec już zaistniałych i potencjalnych skutków nasuwają się pytania:

- Co zrobić, aby powstrzymać regresywne tendencje?

- Jak odwrócić zgubne trendy dla wschodniego pogranicza?

Wielką szansą na zdyskontowanie zgubnych, regresywnych tendencji jest członkostwo Polski w Unii Europejskiej, a w tym Program Operacyjny Rozwój Polski Wschodniej. W ramach tego programu są realizowane projekty o kluczowym znaczeniu dla rozwoju społeczno-gospodarczego pięciu województw. Finansowane są przede wszystkim inwestycje w zakresie infrastruktury wspierającej działalność naukową i badawczą oraz zakładające modernizację miejskich lub regionalnych systemów komunikacyjnych. Realizowane są także przedsięwzięcia zwiększające atrakcyjność inwestycyjną, a tym samym gospodarczą tego obszaru. Program Operacyjny Rozwój Polski Wschodniej (PO RPW) stanowi dodatkowy element wsparcia z funduszy strukturalnych, który wzmocni działanie innych programów na obszarze województwa warmińsko-mazurskiego, podlaskiego, lubelskiego, podkarpackiego oraz świętokrzyskiego (rycina 1). 
Rycina 1. Województwa objęte programem Rozwój Polski Wschodniej

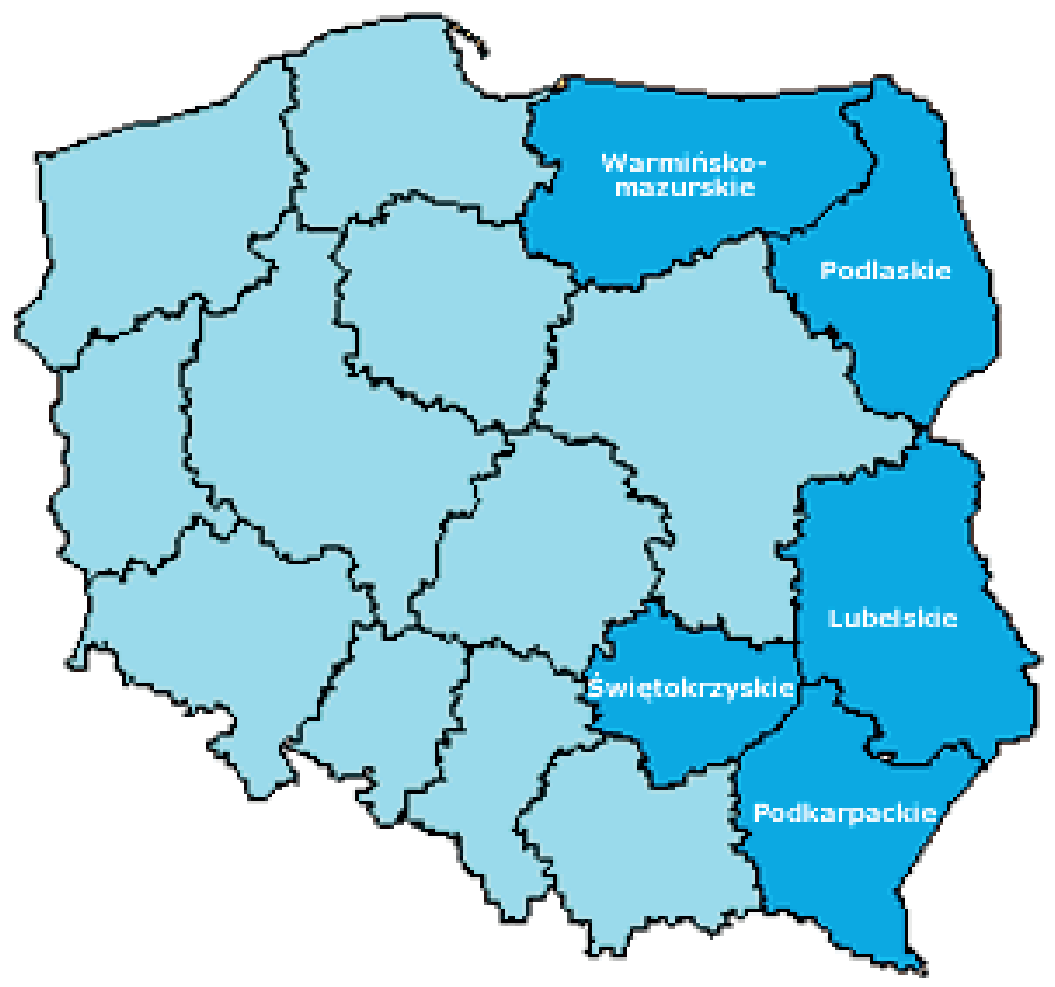

Źródto: Oficjalna strona internetowa Polski Wschodniej: www.polskawschodnia.gov.pl

PO RPW jest jednym z instrumentów polityki regionalnej, do której ponadto należą regionalne programy operacyjne wdrażane przez samorządy województw oraz krajowe programy operacyjne: Innowacyjna Gospodarka, Infrastruktura i Środowisko, Kapitał Ludzki, Pomoc Techniczna oraz programy Europejskiej Współpracy Terytorialnej. Program ten stanowi więc dodatkowy element wsparcia z funduszy strukturalnych, który wzmocni działanie innych programów na obszarze Polski Wschodniej.

Program Rozwój Polski Wschodniej jest realizowany ze środków UE (Europejski Fundusz Rozwoju Regionalnego) oraz krajowych środków publicznych. Głównym celem PO RPW jest przyspieszenie tempa rozwoju społeczno-gospodarczego Polski Wschodniej w zgodzie z zasadą zrównoważonego rozwoju". Natomiast cele szczegółowe to:

- stymulowanie rozwoju konkurencyjnej gospodarki opartej na wiedzy, 
- zwiększenie dostępu do Internetu szerokopasmowego w Polsce Wschodniej,

- rozwój wybranych funkcji metropolitalnych miast wojewódzkich,

- poprawa jakości powiązań komunikacyjnych województw Polski Wschodniej,

- zwiększenie roli zrównoważonej turystyki w rozwoju makroregionu,

- optymalizacja procesu realizacji PO RPW.

Realizacja Programu bazuje na VI priorytetowych osiach z uwzględnieniem systemu organizacyjnego funduszy europejskich.

Oś priorytetowa I: Nowoczesna gospodarka; infrastruktura uczelni, instrumenty inżynierii finansowej, wspieranie innowacji, promocja i współpraca.

Oś priorytetowa II: Infrastruktura społeczeństwa informacyjnego; sieć szerokopasmowa dostępu do Internetu w Polsce Wschodniej.

Oś priorytetowa III: Wojewódzkie ośrodki wzrostu; systemy miejskiego transportu zbiorowego, infrastruktura turystyki kongresowej i targowej.

Oś priorytetowa IV: Infrastruktura transportowa; infrastruktura drogowa.

Oś priorytetowa V: Zrównoważony rozwój potencjału turystycznego na bazie warunków naturalnych; promowanie zrównoważonego rozwoju turystyki, trasy rowerowe.

Oś priorytetowa VI: Pomoc techniczna; wsparcie procesu wdrażania oraz promocja programu.

$\mathrm{Na}$ system organizacyjny funduszy europejskich składają się trzy poziomy, a mianowicie: koordynacja, zarządzanie, wdrażanie. $\mathrm{Z}$ kolei na każdym z tych poziomów działają inne instytucje. Są to: Instytucje Koordynujące i Monitorujące - na etapie koordynacji i monitoringu, Instytucje Zarządzające - na etapie zarządzania oraz Instytucje Pośredniczące i Wdrażające - na etapie wdrażania. Dodatkowo na ostatnim etapie uczestniczą także Instytucje Certyfikujące oraz Instytucja Audytowa.

Instytucją zarządzającą dla Programu Rozwój Polski Wschodniej jest minister rozwoju regionalnego, który odpowiada za skuteczność i prawidłowość zarządzania oraz wdrażanie programu. Obowiązki Instytucji Zarządzającej Programem pełni jednostka organizacyjna w ramach Ministerstwa Rozwoju Regionalnego. Instytucja Zarządzająca powierza realizację części zadań Instytucji Pośredniczącej, którą dla Programu jest Polska Agencja Rozwoju Przedsiębiorczości (PARP). Obowiązki Instytucji Pośredniczącej w ramach PARP pełnią; Departament Infrastruktury Nowoczesnej Gospodarki (osie priorytetowe; I i II), Departament Projektów Infrastrukturalnych (osie priorytetowe; III, IV, V). 
Rycina 2. System organizacyjny PO Rozwój Polski Wschodniej

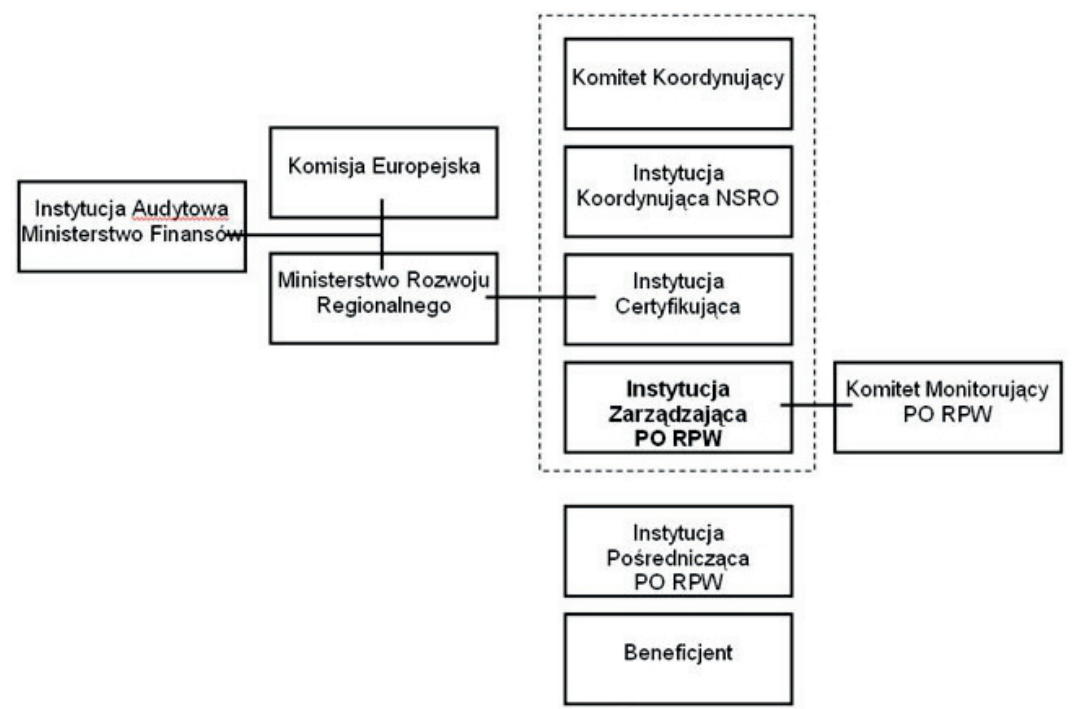

Źródło: Portal wspólfinansowany ze środków Europejskiego Funduszu Rozwoju Regionalnego w ramach Programu Pomoc Techniczna, Ministerstwo Rozwoju Regionalnego, Warszawa 2008.

\subsection{Preferowane kierunki restrukturyzacji gospodarki}

Mając na uwadze unikatowy charakter cech, zasobów i walorów przyrodniczych wschodniego pogranicza Polski, zaleca się priorytet inwestycyjny dla następujących, komplementarnych kierunków:

- rolnictwo ekologiczne i produkcja zdrowej żywności,

- ekoturystyka i agroturystyka,

- racjonalna gospodarka leśna,

- przyrodolecznictwo i lecznictwo uzdrowiskowe,

- nowoczesny przemysł.

\section{Rolnictwo ekologiczne i produkcja zdrowej żywności}

Analizowany obszar wschodniego pogranicza, ze względu na w miarę czyste środowisko przyrodnicze i koncepcję przekształceń rolnictwa konwencjonalnego, stanowi atrakcyjny region dla różnych form ekologizacji gospodarki żywnościowej. Sukcesywne wprowadzanie rolnictwa ekologicznego jest szansą dla zachowania walorów i rozwijania funkcji rekreacyjnej oraz ekologicznej, co może mieć wpływ na łagodzenie problemu bezrobocia i depopulacji. W polityce regionalnej przyjmuje się, że rolnictwo będzie nadal podstawowym źródłem utrzymania ludności ,ściany wschodniej." Wymaga to jednak dostosowania kierunków produkcji do istniejących 
warunków przyrodniczych, wymusza ochronę najlepszych gleb, radykalną poprawę infrastruktury technicznej i polepszenie obsługi produkcyjnej. Szansą wzmocnienia bazy ekonomicznej jest przekształcenie rolnictwa konwencjonalnego w ekologiczne i powiązanie z produkcją zdrowej żywności. Jest to również szansa generowania koncepcji zrównoważonego rozwoju i minimalizacji antropopresji, będącej skutkiem utrzymywania także rolnictwa tradycyjnego.

Stopniowe odchodzenie od rolnictwa konwencjonalnego oznacza konieczność tworzenia i wspierania większych gospodarstw rodzinnych, propagowania proekologicznych form w rolnictwie oraz rozwoju zakładów produkujących maszyny do produkcji zdrowej żywności. Formą zachęcenia do zmian mogą być regionalne targi zdrowej żywności, które z czasem zostaną przekształcone w giełdy zdrowych produktów żywnościowych.

Zainteresowanie produkcją zdrowej żywności rozwijane będzie poprzez wspieranie stowarzyszeń producentów. Znaczącą rolę w tych przekształceniach przypisuje się przyszłym pokoleniom, dlatego należy wprowadzać w szkołach średnich o profilu rolniczym oraz na wyższych uczelniach specjalizacje w zakresie rolnictwa ekologicznego i produkcji zdrowej żywności.

Kluczowym zagadnieniem rozwoju rolnictwa ekologicznego i produkcji zdrowej żywności jest wykreowanie rynku zbytu dla tego rodzaju produktów. Uznaje się za niezbędne promowanie i pomoc w organizowaniu eksportu zdrowej żywności głównie do krajów Unii Europejskiej. W celu tworzenia rynku zbytu zdrowej żywności niezbędne są działania prawne ograniczające produkcję tej żywności na obszarach o skażonym środowisku.

\section{Ekoturystyka i agroturystyka}

Proekologiczna polityka państwa pozwala na kreowanie i wdrażanie ekoturystyki jako nowoczesnej formuły realizacji ekonomicznych zdrowotnych celów rekreacji. Obszar wschodniego pogranicza uznaje się za szczególnie predestynowany w skali kraju do rozwoju ekoturystyki. Efektywne gospodarowanie zasobami przyrody jest jednak utrudnione wskutek niedostatku ofert propagujących proekologiczne treści w rekreacji. Zbyt małe jest również zainteresowanie proekologicznymi formami turystyki przez inwestorów zagranicznych.

Brak umiejętnego inspirowania przez samorządy lokalne i administrację państwową rozwoju turystyki jako gałęzi gospodarki narodowej ugruntowuje pogląd, że uzyskiwanie dochodów z niej stoi w sprzeczności z zachowaniem wymogów ochrony środowiska. Sprzeczność ta jest szczególnie zauważalna w rejonach o silnej antropopresji turystycznej. Za podstawowy kierunek rozwoju turystyki przyjmuje się maksymalne dostosowanie rodzaju i form zagospodarowania turystycznego do walorów przyrodniczych oraz kulturowych, szukając w tym szansy na rozwój i eliminowanie sytuacji konfliktogennych z punktu widzenia ochrony środowiska. Za 
konieczne dla realizowania tego kierunku $\mathrm{w}$ ramach zrównoważonego rozwoju uznaje się:

- zagospodarowanie zasobów wzdłuż ponadregionalnych tras turystycznych oraz baz dla turystyki kwalifikowanej,

- wspieranie rozwoju małych obiektów turystycznych o różnych formach własności, szczególnie pensjonatów zarządzanych rodzinnie, które dają szanse na wydłużenie sezonu turystycznego i podniesienie poziomu usług,

- uporządkowanie zagospodarowania przestrzennego przez ustanowienie wymogów lokalizacji trwałej bazy turystycznej, zwłaszcza hotelarskiej, w powiązaniu z jednostkami systemu osadniczego.

Agroturystyka stanowi szansę dodatkowego dochodu dla gospodarstw rolnych, a ponadto jest to forma bezpośredniego kontaktu konsumentów z przyrodą. Głównymi motywami korzystania z tego typu usług są: potrzeba relaksu, spokoju, możliwość obcowania z przyrodą, stosunkowo niskie ceny.

Elementem dynamizującym rozwój agroturystyki powinno być łączenie jej z innymi komplementarnymi funkcjami: lecznictwem sanatoryjnym, produkcją zdrowej żywności, rekreacją. Ochrona zasobów przyrodniczych przed antropopresją oraz opłacalność proekologicznych form turystyki to kluczowe zagadnienia jej rozwoju na obszarach przyrodniczo cennych. Zatem niezbędne jest tworzenie warunków prawno-finansowych umożliwiających samorządom lokalnym uzyskiwanie większych dochodów z turystyki.

Przewiduje się wprowadzenie zachęt ekonomicznych do podejmowania działań na rzecz popularyzacji i rozwoju agroturystyki.

\section{Racjonalna gospodarka leśna}

Wprowadzenie proekologicznego modelu gospodarki leśnej na obszarze wschodniego pogranicza wymaga przyjęcia powszechnego stosowania naturalnego kierunku w hodowli lasu. Za pożądany przyjmuje się wzrost zalesień gatunkami rodzimymi, zwłaszcza nieużytków i gleb słabych, a także wprowadzanie zadrzewień śródpolnych oraz opasek biologicznych wokół jezior. Działania te powinny doprowadzić do zwiększenia lesistości w granicach $33 \%$ w bliższej perspektywie i do $35 \%$ w dalszej. Uznaje się za niezbędne ograniczenie dostępności do dóbr leśnych, służące zachowaniu ich funkcji ekologicznych i ogólnospołecznych. Równie ważne jest objęcie szczególną kontrolą melioracji i chemizacji na terenach leśnych.

Istnieje także potrzeba dokonania rewizji systemu finansowego w gospodarce leśnej. Postuluje się opracowanie sposobu rekompensaty pieniężnej dla właścicieli lasów za wprowadzanie inicjatyw służących funkcjom ekologicznym i ogólnospołecznym. Niezbędnym jest wprowadzenie opłat za gospodarcze użytkowanie lasu, np. za korzystanie z urządzeń turystycznych i infrastrukturalnych w lasach. Zasadne 
byłoby również ustanowienie podatku na rzecz budżetów lokalnych od każdej powierzchni leśnej.

Gospodarka leśna zorientowana też na realizację funkcji ochronnych i społecznych, stanowi ważne ogniwo koncepcji zrównoważonego rozwoju. Ponadto las, będąc elementem krajobrazu, jest naturalną bazą rozwoju ekoturystyki i przyrodolecznictwa. Odgrywa więc wiodącą rolę jako ważne ogniwo w łańcuchu gospodarki proekologicznej.

\section{Przyrodolecznictwo i lecznictwo uzdrowiskowe}

Brak jak dotąd tradycji, zainteresowania i pełnego rozpoznania warunków naturalnych rozwoju lecznictwa uzdrowiskowego powoduje, że ewentualni kontrahenci nie są w stanie uzyskać koniecznych informacji o możliwościach inwestowania. Jednocześnie istniejący system prawno-finansowy nie zachęca inwestorów do zajmowania się przyrodolecznictwem, lecznictwem sanatoryjnym czy uzdrowiskowym.

Rozwijanie omawianych dziedzin jest kapitałochłonne, dlatego w pierwszej kolejności należy promować przyrodolecznictwo, tworząc sieć stacji klimatyczno-zdrowotnych. Do tego celu można wykorzystać zasoby lokalowe upadających wsi w strefie przygranicznej, stanowiące potencjalną bazę lecznictwa psychoklimatycznego i detoksykacyjnego dla ludności z obszarów ekologicznego zagrożenia. W programie należy uwzględnić również tworzenie warunków zachęcających do rozszerzania plantacji roślin ziołowych i leczniczych, mających także istotne znaczenie dla rolnictwa ekologicznego. Za celowe i ważne uznaje się też upowszechnianie wiedzy o możliwościach rozwoju form kuracji takich jak np. bioterapia, apiterapia, spacery lecznicze, radiestezja, obserwacja przyrody.

Do miejscowości o rzeczywistych lub potencjalnych funkcjach wypoczynkowo-uzdrowiskowych wschodniego pogranicza można zaliczyć: Gołdap, Augustów, Supraśl, Mielnik, Nałęczów, Kazimierz Dolny, Ustrzyki Dolne, Busko Zdrój, Solec Zdrój.

Lecznictwo uzdrowiskowe, podobnie jak turystyka, stanowi szansę zasilenia budżetów administracji terenowej, co może mieć wpływ na aktywizację regionu. Kapitał niezbędny na rzecz rozwoju lecznictwa uzdrowiskowego powinien być skierowany przede wszystkim na:

- poprawę stanu czystości powietrza atmosferycznego i wód powierzchniowych,

- budowę obiektów sanatoryjnych z uwzględnieniem infrastruktury technicznej,

- wprowadzanie nowych uregulowań prawnych w odniesieniu do realizacji koncepcji zrównoważonego rozwoju. 
Komplementarny rozwój ekoturystyki i lecznictwa uzdrowiskowego pozwoli na wzajemne wspieranie się tych dziedzin, np. przez wykorzystanie wspólnej infrastruktury a także popularyzowanie turystyki zdrowotnej.

Uzupełniającą, ale bardzo ważną i atrakcyjna formą zagospodarowania zasobów na obszarze wschodniego pogranicza, może być przyrodolecznictwo. W naturalnym krajobrazie inwestowanie w rozwój plantacji ziół oraz hodowlę pszczół ma duże szanse powodzenia.

\section{Nowoczesny przemysł}

Za celowe i uzasadnione uznaje się propagowanie na wschodnim pograniczu Polski lokalizacji przemysłu o „czystych” technologiach, zamkniętych obiegach, „czystych” produktach, wykorzystującego na zasadzie rewitalizacji niezagospodarowane obiekty, zasoby pracy i potencjał naukowo-techniczny. Za szczególnie pożądany uważa się rozwój przemysłu opartego na lokalnych surowcach, zwłaszcza rolno-spożywczych, ekofarmaceutycznych, materiałach budowlanych, drzewnych oraz tzw. przemysłu „czystego”, wymagającego nieskażonego środowiska.

Warunkiem rozwijania nowoczesnego proekologicznego przemysłu jest rozwój specjalistycznego potencjału naukowo-technologicznego. Powstający w Białymstoku Park Naukowo-Technologiczny stanowi klasyczny przykład kształtowania nowej rzeczywistości i świadomości społecznej w zakresie paradygmatu zrównoważonego rozwoju i gospodarki opartej na wiedzy. Jest to ważny krok w kierunku generowania i wdrażania cywilizacji informacyjnej.

\section{Rola samorządu terytorialnego w rozwoju regionalnym}

Samorząd terytorialny to organizacja społeczności lokalnej (gmina, powiat) lub regionalnej (województwo samorządowe) i jednocześnie forma administracji publicznej. Mieszkańcy z mocy prawa tworzą wspólnotę i względnie samodzielnie decydują o realizacji zadań administracyjnych wynikających z potrzeb i dozwolonych przez ustawy, pod nadzorem administracji rządowej. Samorząd rozumiany jako organizacja jest przymusową korporacją prawa publicznego mieszkańców danego obszaru, mających wspólne interesy i potrzeby. Ustawodawca powierza samorządowi uprawnienie stanowienia prawa miejscowego i wykonywanie większości zadań z zakresu administracji lokalnej.

Samorząd terytorialny jest najważniejszą formą samorządności rozumianej jako przesunięcie w obrębie administracji publicznej kompetencji do załatwiania pewnej grupy spraw, co polega na odebraniu ich scentralizowanej administracji rzą- 
dowej i powierzeniu do samodzielnego rozwiązywania grupie społecznej, której te sprawy dotyczą. ${ }^{140}$

Rola samorządu terytorialnego jest zdeterminowana systemem polityki gospodarczej państwa. Skuteczność natomiast działalności władz regionalnych i gminnych zależy od zasad ustrojowych państwa, od ram prawnych, a w szczególności od:

- racjonalności podziału administracyjnego kraju,

- przejrzystości i stabilności porządku konstytucyjnego,

- proporcji wpływów do budżetów: centralnego, regionalnych i gminnych,

- skali samodzielności i elastyczności finansowej władz lokalnych.

Stosowanie w praktyce tych zasad zapewnia sprawne i stabilne funkcjonowanie instytucji samorządowych, co pozwoli osiągnąć następujące cechy:

- pomoc w układzie przestrzennym, a nie tradycyjnym sektorowym,

- wsparcie nowoczesnych sektorów gospodarki, a nie tradycyjnych,

- promowanie przedsięwzięć przede wszystkim w szeroko rozumianych usługach,

- orientacja skierowana głównie na małe i średnie przedsiębiorstwa,

- promowanie rozwoju opartego na własnych zasobach i cechach regionu,

- kreowanie podmiotów i inicjatyw lokalnych przez władze samorządowe,

- promowanie prywatyzacji gospodarki oraz wspólnych przedsięwzięć sektorowych,

- wspieranie rozwoju infrastruktury tworzącej korzystne warunki dla gospodarki.

Samorząd odgrywa główną rolę w procesie rozwoju gospodarczego, jako:

- przywódca w tworzeniu całościowej lokalnej polityki gospodarczej,

- administrator tworzonych oddolnie programów i projektów gospodarczych,

- inicjator programów rozwoju gospodarczego głównie poprzez dostarczanie funduszy publicznych, tworzenie zachęt dla inwestorów, skuteczne stymulowanie wzrostu przedsiębiorczości, promocję małych i średnich przedsiębiorstw, regulację prawa.

Obok wiodącej roli samorządu w lokalnym rozwoju gospodarczym bardzo ważna jest rola przedsiębiorstw. To właśnie uczestnictwo przedsiębiorców w planowaniu rozwoju lokalnego pomaga stworzyć korzystne warunki dla klimatu gospodarczego, a tym samym dla stabilnego rozwoju ekonomicznego gminy i kształtowania społeczeństwa obywatelskiego.

Tryb dostępu: http://poradnik.ngo.pl/x/440975, dnia 02.12.2012 r. 


\subsection{Cechy i rola społeczeństwa obywatelskiego}

Z definicji społeczeństwa obywatelskiego wynika, że głównym elementem a zarazem główną determinantą rozwoju społeczeństwa obywatelskiego są jego obywatele. Obywatele świadomi, aktywni, w swoich działaniach potwierdzający wysoki poziom podmiotowości społecznej, ekonomicznej i politycznej.

Obywatelski wymiar tej podmiotowości wyraża się najczęściej w postaci tworzonych przez nich instytucji, organizacji pozarządowych zdolnych artykułować potrzeby i interesy określonych środowisk i grup społecznych, zdolnych wypełniać funkcje i realizować zadania służące zaspokojeniu potrzeb społecznych, prowadzić działalność pożytku publicznego we współpracy z instytucjami administracji publicznej.

Konsekwentni, świadomi i aktywni obywatele stanowią potencjał tworzący aktywne wspólnoty, urzeczywistniając podstawowe zasady i wartości demokratycznego ładu społecznego, opartego na więziach społecznych. Aktywne wspólnoty, zorganizowane w sposób formalny lub występujące jako grupy nieformalne, stanowią główną determinantę rozwoju kapitału społecznego jako szczególnej syntezy potencjału zasobów ludzkich, instytucji publicznych i pozarządowych, infrastruktury społecznej oraz wzajemnych relacji między nimi. ${ }^{141}$ „Organizacje pozarządowe tworzą kanały reprezentacji i rzecznictwa interesów poszczególnych grup i mechanizmów ich uzgadniania. W nich uczymy się wspólnego działania i mamy okazję praktykować reguły demokratyczne. To tam możliwe jest działanie na rzecz dobra wspólnego na zasadzie wsparcia organizacji pozarządowych". ${ }^{142}$

Dla pełnego obrazu struktury społeczeństwa obywatelskiego i determinant jego rozwoju należy dodać całe instytucjonalne i funkcjonalne podłoże integracji społecznej, rozumianej jako „działania wspólnotowe oparte na zasadach dialogu, wzajemności i równorzędności, których celem jest dążenie do społeczeństwa opartego na demokratycznym współuczestnictwie, rządach prawa i poszanowania różnorodności kulturowej, w której obowiązują i są realizowane podstawowe prawa człowieka i obywatela oraz skutecznie wspomagane są jednostki i grupy w realizacji ich celów życiowych”. ${ }^{143}$ Należy także mieć na uwadze, iż ,społeczeństwo obywatelskie jest pewnym typem środowiska moralnego, umożliwiającym wszechstronny rozwój człowieka jako istoty społecznej, zdolnej do nawiązywania i podtrzymywania, wbrew przeciwnościom, solidarnej więzi z innymi i zdolnej do realizacji zespołu idei demokratycznych - opartych na godności, rozumie, wolności i odpowiedzialności”. ${ }^{144}$

\footnotetext{
141 Por. H. Sasinowski, M. Lisowski, Miejsce i rola społeczeństwa obywatelskiego w okresie transformacji, [w:] Państwo i prawo wobec współczesnych wyzwań, red. R. Czarny, K. Spryszak, Toruń 2012, s. 479.

142 P. Frączak, Głos w dyskusji na temat wizji rozwoju społeczeństwa obywatelskiego w Polsce, 2005, materiał powielony w zbiorach autora.

143 Narodowa Strategia Integracji Społecznej dla Polski, Warszawa 2004, s. 25.

144 P. Frączak, Głos..., op. cit.
} 


\section{Podsumowanie}

Rozwój społeczno-gospodarczy regionów jest zależny w dużym stopniu od systemu politycznego i gospodarczego kraju, a tym samym od polityki regionalnej. Czynnikiem stymulującym rozwój i aktywizację zasobów jest polityka regionalna ukierunkowana na umacnianie regionalnej i lokalnej innowacyjności, inwencji oddolnej i przedsiębiorczości. Narzędziem generującym mobilność władz samorządowych jest polityka interregionalna (rządowa), a szczególnie intraregionalna (samorządowa) prowadzona wobec regionów.

Na bazie położenia i uwarunkowań przyrodniczych konieczna jest intensywna restrukturyzacja wschodnich regionów Polski na tle koncepcji oraz paradygmatu zrównoważonego rozwoju i gospodarki opartej na wiedzy. Preferowane kierunki rozwoju o charakterze proekologicznym to: rolnictwo ekologiczne, eko- i agroturystyka, racjonalna gospodarka leśna, gospodarka wodna, przyrodolecznictwo i ziołolecznictwo, przemysł nowoczesnych technologii. Przy takim założeniu istnieje duża szansa aktywizacji zdegradowanych zasobów wschodniego pogranicza, a tym samym rozwoju i poprawy warunków życia ludności. 


\section{THE CONCEPT OF RESTRUCTURING AND REGIONAL DEVELOPMENT OF POLAND'S EASTERN BORDER}

Social and economic regional development depends much on the political as well as economic system of a country and consequently, on regional policy. It is regional policy aimed at regional and local innovation and grassroots movement, that stimulates development and the activation of resources. What generates mobility of local authorities is interregional (governmental) and intraregional (local) policy towards the regions.

Location and environmental conditions make it necessary to extensively restructure the Eastern regions of Poland, based on the concept of balanced development and economy founded on knowledge. The preferred pro ecological directions of development are: ecological agriculture, eco- and agritourism, rational forestry, water management, physiotherapy, phytotherapy and modern technology industries. Therefore, there is a good chance to activate the degraded resources of the Eastern border region, resulting in the development and improvement of living conditions for its population.

Keywords:

Restructuring, region, sustainable development, regional policy 